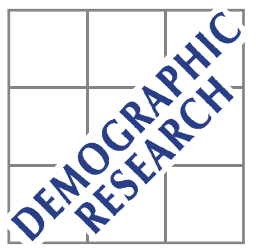

Demographic Research a free, expedited, online journal of peer-reviewed research and commentary in the population sciences published by the Max Planck Institute for Demographic Research Konrad-Zuse Str. 1, D-18057 Rostock · GERMANY www.demographic-research.org

DEMOGRAPHIC RESEARCH

VOLUME 23, ARTICLE 22, PAGES 615-654

PUBLISHED 17 SEPTEMBER 2010

http://www.demographic-research.org/Volumes/Vol23/22/

DOI: $10.4054 /$ DemRes.2010.23.22

Research Article

\title{
The relationship context of nonmarital childbearing in the U.S.
}

Jennifer Manlove

Suzanne Ryan

Elizabeth Wildsmith

Kerry Franzetta

\section{(C)2010 Jennifer Manlove et al.}

This open-access work is published under the terms of the Creative Commons Attribution NonCommercial License 2.0 Germany, which permits use, reproduction \& distribution in any medium for non-commercial purposes, provided the original author(s) and source are given credit. See http:// creativecommons.org/licenses/by-nc/2.0/de/ 


\section{Table of Contents}

1 Introduction $\quad 616$

$2 \quad$ Background 618

2.1 Mothers' sociodemographic characteristics and relationship context 619

2.2 Mothers' family formation histories and relationship context 620

$2.3 \quad$ Fathers' characteristics and relationship context 621

2.4 Racial/ethnic homogamy and racial/ethnic differences in 622 relationship context

3 Data and methods $\quad 623$

$\begin{array}{ll}3.1 & \text { Data and sample }\end{array}$

$\begin{array}{lll}3.2 & \text { Measures } & 625\end{array}$

$\begin{array}{lll}3.3 & \text { Methods } & 627\end{array}$

$4 \quad$ Results $\quad 628$

$4.1 \quad$ Relationship context at birth, by race/ethnicity 628

4.2 Factors associated with relationship status at birth, full sample $\quad 630$

4.3 Factors associated with relationship status at birth, restricted 632

sample

$5 \quad$ Summary and discussion $\quad 635$

5.1 Levels and trends in nonmarital and cohabiting births in the U.S. $\quad 635$

5.2 Mother and father correlates of relationship status at birth 637

$5.3 \quad \mathrm{Racial} / \mathrm{ethnic}$ variation in correlates of relationship status at birth $\quad 639$

5.4 Limitations 640

6 Conclusion 641

$7 \quad$ Acknowledgements $\quad 642$

$\begin{array}{ll}\text { References } & 643\end{array}$

$\begin{array}{ll}\text { Appendix } & 651\end{array}$ 


\title{
The relationship context of nonmarital childbearing in the U.S.
}

\author{
Jennifer Manlove ${ }^{1}$ \\ Suzanne Ryan ${ }^{2}$ \\ Elizabeth Wildsmith ${ }^{3}$ \\ Kerry Franzetta ${ }^{4}$
}

\begin{abstract}
Using Early Childhood Longitudinal Study-Birth Cohort data, we present estimates of nonmarital births in the United States in 2001, both within and outside of cohabiting unions. We additionally examine how mother and father characteristics are associated with the relationship context at birth, and assess racial/ethnic differences in these relationships. We find that $52 \%$ of nonmarital births (and 19\% of all births) occur within cohabitating unions - a substantial increase in cohabiting births since the early 1990s. The increase in cohabiting births among white and Hispanic women largely reflects a shift from marital to cohabiting births, while the increase in cohabiting births among black women largely reflects a shift from single to cohabiting births. Mother and father characteristics, including marital and fertility histories, are associated with relationship status at birth. However, with the exception of mother's education, only the association between father characteristics and relationship status at birth vary by race and ethnicity.
\end{abstract}

${ }^{1}$ Child Trends, Washington, D.C. 4301 Connecticut Avenue, NW, Suite 350, Washington, D.C. 20008, USA. E-mail: jmanlove@childtrends.org.

${ }^{2}$ Child Trends, Washington, D.C. 4301 Connecticut Avenue, NW, Suite 350, Washington, D.C. 20008, USA.

E-mail: suzanne.ryan@nih.gov.

${ }^{3}$ Child Trends, Washington, D.C. 4301 Connecticut Ave, NW Suite 350 20008, USA.

E-mail: EWildsmith@childtrends.org.

${ }^{4}$ Chapin Hall Center for Children, USA. E-mail: kfranzetta@chapinhall.org. 
Manlove et al:: The relationship context of nonmarital childbearing in the U.S.

\section{Introduction}

Most countries in the advanced industrialized world - including countries in western and northern Europe, as well as the United States and Canada in North America-have experienced radical transformations in family formation and childbearing since the 1960s. The most notable structural changes have been the delay and decline in marriage and childbearing, which have been coupled with substantial changes in attitudes and values related to family life, childbearing, living arrangements, and sexuality; together these changes have been labeled the Second Demographic Transition (SDT) (Kalmijn 2007; Kiernan 2004a; Lesthaeghe and Neidert 2006; Liefbroer and Dourleijn 2006; Neyer and Andersson 2004; Perelli-Harris et al. 2010; Sobotka 2008). More recently, since the late 1980s and early 1990s, central and eastern European countries have undergone similar transformations (Neyer and Andersson 2004; Perelli-Harris et al. 2010; Sobotka and Toulemon 2008).

One manifestation of these changes has been the below replacement-level fertility-i.e., a Total Fertility Rate (TFR) of under 2.1 - seen in much of Europe. This shift has garnered much attention, as these countries attempt to grapple with the social and political consequences of an aging population (Vos 2009). Another important manifestation - and the aspect that has been the disproportionate focus of attention in the United States - is the increase in the proportion of births that occur outside of marriage (Bachrach, Hindin, and Thomson 2000; Perelli-Harris et al. 2010; Sobotka 2008; Wu and Wolfe 2001). In 2007, 39.7\% of all births in the U.S. were to unmarried women, up from 18.4\% of births in 1980 (Martin et al. 2009; Ventura 2009). There are, however, large racial/ethnic variations in nonmarital fertility within the U.S., with Hispanic and black women having the highest rates, and white and Asian women the lowest rates (Martin et al. 2009; Ventura 2009). Europe experienced similar increases in nonmarital fertility; in fact, although substantial variations persist between countriesas well as between regions and ethnicities within countries-nonmarital childbearing has become standard in some European countries (Kiernan 2004b; Neyer and Andersson 2004; Sobotka and Toulemon 2008).

The rapid increase in nonmarital childbearing has drawn concern as an extensive body of research documents that children do best when they grow up with two married biological parents in a low-conflict relationship (Amato 2000; McLanahan and Sandefur 1994; Seltzer 2000), and that women have more positive outcomes themselves when they have a marital rather than a nonmarital birth (Driscoll et al. 1999; Hamplova and Bourdais 2009; Lichter and Graefe 2001; Moore 1995; Soons and Kalmijn 2009; Upchurch, Lillard, and Panis 2001). Nonmarital childbearing is not synonymous with single parenthood, however (Sigle-Rushton and McLanahan 2002). Much of the increase in nonmarital fertility, across all countries, is attributable to changes in cohabitation; specifically, to the increased number of people entering cohabiting unions, 
the increased duration of cohabiting unions, and the decreased likelihood of marriage in response to a pregnancy (Raley 2001; Sobotka and Toulemon 2008).

In the U.S., the percentage of nonmarital births occurring to cohabiting couples increased from $29 \%$ in the early 1980 s to $39 \%$ in the early 1990s (Bumpass and $\mathrm{Lu}$ 2000 ), and more recent estimates suggest that roughly half of nonmarital births in the late 1990s and early 2000s (and 18\% of all births) were to cohabiting couples (Kennedy and Bumpass 2008; Sigle-Rushton and McLanahan 2002). Evidence suggests that cohabitation differs from both marriage and single parenthood in the resources available to children, particularly in the U.S. (Acs and Nelson 2001; Nelson, Clark, and Acs 2001). Thus, research seeking to understand the circumstances into which children are born should distinguish not only between marital and nonmarital births, but also between nonmarital births that occur within and outside of cohabiting unions.

Using data from the Early Childhood Longitudinal Study-Birth Cohort (ECLS-B), we pursue three objectives. First, we verify the most recent estimates of nonmarital childbearing in the U.S., and particularly cohabiting nonmarital births, for a nationally representative sample of children, with particular attention paid to racial/ethnic differences. Despite the fact that unmarried parents have been the direct focus of much U.S. policy in recent years (e.g., The Personal Responsibility and Work Opportunity Act of 1996 and The Deficit Reduction Act of 2005), surprisingly few studies have examined the relationship status of unmarried parents at the time of birth (Kennedy and Bumpass 2008; Sigle-Rushton and McLanahan 2002). Second, recognizing that union formation and childbearing decisions are made within the context of a relationship (Huinink and Feldhaus 2009; Seltzer et al. 2005; Sigle-Rushton and McLanahan 2002; Ventura et al. 1995), we examine both the mother and the father characteristics associated with the parental relationship context at the time of a child's birth. Finally, recognizing the racial and ethnic diversity both in the prevalence of nonmarital fertility in the U.S., and in the role cohabitation plays in the family system, we determine whether the factors associated with relationship context at birth vary by race/ethnicity. A key strength of our research is the use of nationally representative data that have recently become available. The data include reports of both mother and father factors, which allow us to examine how the characteristics of women, their families, and their partners are associated with the relationship context at birth; and to compare women who were cohabiting or who were not coresiding with the biological father of the focal child, to women who were married at the time of birth. 
Manlove et al:: The relationship context of nonmarital childbearing in the U.S.

\section{Background}

The increase in nonmarital fertility across advanced industrialized countries is the result not only of changes in childbearing behavior, but also of changes in union formation (i.e., delays and declines in marriage, increases in cohabitation). Although there is no consensus as to what has caused these changes in family structure, the dominant explanations in the social sciences have focused on two broad observations: 1) that structural/economic changes have reduced the gains associated with marriage, particularly for those with fewer socioeconomic resources; and 2) that ideational/value changes have increased the autonomy of individuals, and reduced the stigma associated with non-normative family trajectories (Bachrach, Hindin, and Thomson 2000; Cherlin 2004; Perelli-Harris et al. 2010; Seltzer et al. 2005). One notable difference between these two hypotheses is that, while economic explanations generally assume that change in family formation behavior begins with those with more limited resources, valuechange explanations (i.e., the Second Demographic Transition) generally assume that change begins with the more educated (Perelli-Harris et al. 2010).

While an extensive body of research has evaluated cultural and economic explanations for family change, there has been growing pressure in both the U.S. and Europe for researchers to draw more of their observations from the life course perspective, and to pay greater attention to the role of women's and men's characteristics in fertility and union behavior (Huinink and Feldhaus 2009; Seltzer et al. 2005). The life course perspective argues that life transitions can be best understood within the context of individuals' social relationships and personal histories (Bengston and Allen 1993; Bronfenbrenner 1979). A key aspect of this perspective is the principle of "linked lives," which contends that we live interdependently, and are influenced by our network of shared relationships (Elder 1998, Huinink and Feldhaus 2009). Even though it is clear that decisions about union formation and childbearing are made within the context of relationships, surprisingly little research takes into account the role that mother and father characteristics play in either the transition to a nonmarital birth, or in the relationship context of that birth (Huinink and Feldhaus 2009; Seltzer et al. 2005; Sigle-Rushton and McLanahan 2002; Ventura et al. 1995). The linked lives concept further posits that past history shapes future actions, suggesting that we focus not only on the individual characteristics of mothers and fathers, but also on each of their family and relationship context. Thus, in our analyses, we include information from both the biological mothers and fathers of children - focusing on their individual characteristics, their family backgrounds, and their marriage and fertility histories - with the goal of shedding light on how the characteristics of couples influence the relationship context at birth.

It is increasingly clear that there is a great deal of diversity both across, and within, countries in the type and pace of family change, and that this variation is linked to a 
country's specific social and historical context (Fussell, Gauthier, and Evans 2007; Kalmijn 2007; Kiernan 2004b; Liefbroer and Dourleijn 2006; Sobotka 2008; Vos 2009). While many countries share general trajectories of family change, countryspecific patterns emerge that are the result of the interaction between micro-level and macro-level factors (Neyer and Andersson 2004). For example, while increased education among women is almost universally linked to delayed childbearing, the size and significance of the association appears to be moderated by other country-specific characteristics, such as policies targeted towards work-family balance (Perelli-Harris et al. 2010). Similarly, the role of cohabitation in the family system (i.e., as an alternative to marriage, a stepping stone to marriage, or an alternative to being single) appears to depend on many factors, including how institutionalized and how diffused cohabitation is within a country (Liefbroer and Dourleijn 2006; Sobotka and Toulemon 2008; Soons and Kalmijn 2009).

Family patterns in the U.S. have been compared to those in many countries, although perhaps most often to those in the U.K., due to the relatively similar social contexts in these countries (Seltzer 2004; Wu and Wolfe 2001). However, research suggests that more traditional values (such as the pro-marriage movement and strong disapproval of premarital sex), along with high levels of racial and ethnic diversity, continue to uniquely shape patterns of family formation in the U.S. (Fussell, Gauthier, and Evans 2007; Heuveline and Timberlake 2004; Kiernan 2004a; Lesthaeghe and Neidert 2006; Seltzer 2004). Notably, the U.S. stands out with its high levels of nonunion fertility (i.e., nonmarital fertility occurring outside of cohabiting unions), high levels of union dissolution (marriage and cohabitation), and high proportion of children experiencing time in a stepfamily (Andersson 2002). Additionally, the role of cohabitation in the family system in the U.S. remains distinct from the patterns observed in European countries (Heuveline and Timberlake 2004). Thus, while our literature review draws from research on factors associated with nonmarital fertility and the relationship context at birth, supplemented by more general research examining correlates of marital/cohabitation status, we disproportionately focus our review on work done in the United States to develop our expectations. In the discussion, we place our findings within a broader international context.

\subsection{Mothers' sociodemographic characteristics and relationship context}

Mothers' sociodemographic factors, as well as their family background characteristics, are associated with nonmarital childbearing across almost all western industrialized countries, although the strength (and sometimes direction) of these associations varies across countries (Kiernan 2001). In the U.S., the highest rates of nonmarital childbearing are seen among women in their teens and twenties, with lower rates among 
Manlove et al:: The relationship context of nonmarital childbearing in the U.S.

women aged 30 or older (Hamilton, Martin, and Ventura 2009). Black and Hispanic women have higher rates of nonmarital childbearing than non-Hispanic whites (Gryn and Mott 2002; Hamilton, Martin, and Ventura 2009), and Hispanics are more likely than black and white women to have births within cohabiting relationships (Bumpass and $\mathrm{Lu} \mathrm{2000).} \mathrm{Additionally,} \mathrm{women} \mathrm{enrolled} \mathrm{in} \mathrm{school} \mathrm{are} \mathrm{less} \mathrm{likely} \mathrm{to} \mathrm{have} \mathrm{a}$ nonmarital birth than those not in school (Upchurch, Lillard, and Panis 2002). Although older women, white women, and more highly educated women are the groups least likely to have a nonmarital birth, bivariate analyses show that, if they do have a child outside of marriage, they are more likely than their counterparts to give birth within a cohabiting union, rather than outside of any union (Mincieli et al. 2007). We expect to find similar associations in multivariate analyses.

Having grown up in an intact or economically advantaged family, and having parents with higher levels of education, are factors associated with lower odds of nonmarital childbearing in the U.S. (South 2001; Upchurch, Lillard, and Panis 2002). Meanwhile, having socioeconomic disadvantages, and having grown up in a non-intact family, are factors associated with an increased risk of having a nonmarital birth outside of a cohabiting relationship in the U.K. (Ermisch 2001). However, expectations with respect to the specific context of nonmarital childbearing in the U.S. are less clear, as there has been relatively little research addressing the question of how family factors influence whether nonmarital births occur inside or outside of a cohabiting union.

\subsection{Mothers' family formation histories and relationship context}

Having previous children, either together or with another partner, shapes the family formation patterns of couples in the U.S. Research indicates that women who have children from previous relationships, especially from nonmarital relationships, face lower chances of subsequently marrying than women without children (Bennett, Bloom, and Miller 1995; Clarkberg, Stolzenberg, and Waite 1995; Lichter and Graefe 2001), and are therefore more likely to have a subsequent nonmarital birth than a marital birth (Driscoll et al. 1999). Other research finds that women with previous children are more likely than childless women to subsequently cohabit than to marry, suggesting that having children from previous relationships may be a barrier to marriage, but not necessarily to forming coresidential unions (Bennett, Bloom, and Miller 1995; Qian, Lichter, and Mellott 2005). However, many couples have prior shared children, and research has shown, for example, that unmarried couples with shared previous children are more likely to be cohabiting or married one year after the birth of the focal child than couples who do not have prior shared children (Carlson, McLanahan, and England 2004). With respect to marital history, previously married women (especially black women) are less likely than never-married women to have a 
nonmarital birth (Upchurch, Lillard, and Panis 2002). The authors speculated that this discrepancy may be due to differences between previously married and never-married women's contraceptive practices or available marriage markets.

Based upon these research studies, we expect to find that women with prior shared children will be more likely to be married than cohabiting or than being outside a coresidential union. On the other hand, we expect that women with children from a previous relationship will be less likely to be married (versus not married) at the birth of a subsequent child than those without other children. However, if these women do form a coresidential union, we expect to find that they will be more likely to be cohabiting than to be married when they have a subsequent birth. In addition, we hypothesize that women who have been previously married will have increased odds of being married at the focal child's birth, net of other factors.

\subsection{Fathers' characteristics and relationship context}

Previous research on fertility- and relationship-related outcomes in the U.S. has found that men's characteristics matter, independently of women's characteristics. For example, a father's earnings and employment status have positive effects on the likelihood that the parents will marry within one year of a nonmarital birth (Carlson, McLanahan, and England 2004). Generally we expect that a father's individual and family background characteristics will operate similarly to a mother's characteristics, and will be associated with a woman's relationship status at a child's birth, over and above the influence of a woman's own attributes.

However, the marital and fertility histories of men tend to operate differently than those of women. Unmarried men who have children from another relationship (especially coresidential children) are more likely than men with no children to form a coresidential (cohabiting or marital) union, especially with a woman who has her own children (Bernhardt and Goldscheider 2002; Goldscheider and Sassler 2006). Additional research indicates that unmarried men who have previous children from a prior union are more likely to form cohabiting unions (compared with staying single) than are men without children (Nock 1998; Stewart, Manning, and Smock 2003). Thus, we hypothesize that women who partner with men who are already fathers may have greater chances of giving birth within coresidential unions, particularly marriages, than those whose male partners are childless. 
Manlove et al:: The relationship context of nonmarital childbearing in the U.S.

\subsection{Racial/ethnic homogamy and racial/ethnic differences in relationship context}

Race/ethnicity is one of the most important social characteristics along which individuals are stratified in the U.S. and the level of racial/ethnic homogamy across all relationship types is high (e.g. marriage, cohabitation, dating). However, there is also evidence of increased homogamy as relationships progress from dating to cohabitation to marriage (Blackwell \& Lichter, 2004). One study finds that racial/ethnic differences between unmarried parents are associated with lower odds of the couple marrying within one year (Carlson, McLanahan, and England 2004), and another study shows that racial/ethnic differences reduces the odds of marriage among cohabiting couples, but only for whites (Sassler and McNally 2003). Sigle-Rushton and McLanahan (2002) also find that the effect of racial/ethnic homogamy on the living arrangements of unmarried mothers depends upon the race/ethnicity of each partner. For unmarried white mothers, partnering with a father of a different race/ethnicity is associated with reduced odds of cohabitation at a child's birth relative to having a white partner, but the opposite is true for black women. For unmarried Hispanic mothers, partnering with a white father is associated with greater odds of cohabiting relative to having a same race/ethnicity partner. We expect that having a male partner of a different race/ethnicity will be associated with a greater likelihood that a woman will be unmarried and cohabiting at the birth of a child, particularly if the mother is black or Hispanic.

There are additional quantitative and qualitative reasons for examining racial/ethnic groups in the U.S. separately, in addition to the racial/ethnic differences in the association between racial homogamy and relationship status at birth. First, there are striking disparities in nonmarital childbearing patterns across racial and ethnic groups. In $2007,27 \%$ of all births to white women were nonmarital, compared to $71 \%$ and $50 \%$ of births to black and Hispanic women, respectively (Martin et al. 2009). There are also striking differences in the relationship statuses of unmarried parents at the birth of the child. In the early $1990 \mathrm{~s}$, approximately $50 \%$ of births to unmarried white and Hispanic couples were to cohabiting parents, compared with only $22 \%$ of nonmarital births to black women (Bumpass and Lu 2000).

Second, a growing body of research suggests that the meaning or role of specific family forms differs across racial/ethnic groups in the U.S., reflecting varying degrees

of access to social and economic resources, as well as exposure to varying cultural and social contexts (East 1998; Forste and Tienda 1996; Heard 2007; Landale and Oropesa 2007; Osborne, Manning, and Smock 2004; Smock 2000). In particular, childbearing outside of a marital union may be more acceptable for black and Hispanic women than for white women, and may be associated with relatively less stigma. Notably, research suggests that cohabitation, and fertility within cohabitation, play very different roles in the U.S. family system for black, white, and Hispanic women (Manning 2001; Wildsmith and Raley 2006). Although there are few racial/ethnic differences in the levels of women currently in cohabiting unions (Chandra et al. 2005), Hispanic women 
(and, to a lesser extent, black women) in cohabiting unions are much more likely to give birth than are white women in cohabiting unions, and they are much more likely than black or white mothers to identify these births as intended (Guzman et al. 2010; Landale and Oropesa 2007; Manning 2001). Additionally, Hispanic and black women are more likely to continue to cohabit after a birth (Manning 2001). Some of these differences likely reflect the socioeconomic disadvantages of Hispanic and black women. Recent research has found that low-income couples cite economic and social barriers to marriage, and thus report choosing to remain in cohabiting or visiting relationships (Edin and Kefalas 2005; Gibson-Davis, Edin, and McLanahan 2005). However, recent research also suggests that a cultural orientation among Hispanics that is more tolerant of cohabitation may contribute to greater rates of cohabiting births for this group, particularly for those born outside the U.S. Informal/consensual unions have a long history in Mexico, in particular, and have long been considered a traditional analog to formal marriage (Castro Martin 2002).

Together this research suggests that different processes may shape the family formation of black, white, and Hispanic women in the U.S. In fact, research has found that socioeconomic status is less strongly associated with nonmarital fertility for racial and ethnic minority women than for white women (Forste and Tienda 1996; Wildsmith and Raley 2006), although relatively few studies have distinguished between nonmarital births that occur inside and outside of cohabiting unions.

\section{Data and methods}

\subsection{Data and sample}

This study uses data from the first wave of the Early Childhood Longitudinal StudyBirth Cohort (ECLS-B), a nationally representative study of 10,688 children born in the U.S. in 2001. Using a clustered, list frame sampling design, infants born to mothers at least 15 years old were selected from birth certificates in the National Center of Health Statistics' (NCHS) vital statistics system (Flanagan and West 2004). Births were selected from 96 counties. The first wave of data was collected in the child's home approximately nine months after the birth of the child, and had a response rate of $74.1 \%$. This wave consisted of four components: a parent interview, child assessments, resident and non-resident father questionnaires, and data from the child's birth certificate. Additional waves of data were collected as the focal children reached ages 24 and 48 months, and when the children entered kindergarten. In this paper, information on mother and father characteristics and data on the relationship of the parents at the time of the child's birth are drawn from the nine-month parent questionnaire (Wave 1) and the birth certificate. 
Manlove et al:: The relationship context of nonmarital childbearing in the U.S.

Two samples are created for the analyses in this paper. The sample for the first set of analyses is drawn from the approximately 10,100 children $^{5}$ who resided with their biological or adoptive mother at Wave 1, whose mothers were younger than age 45 and responded to the parent questionnaire, and who had valid sample weights. Less than $1 \%$ of the cases had to be dropped because we were unable to establish the status of the relationship between the biological mother and biological father at the time of birth. The final analytic sample consists of 10,000 births. For a second set of analyses, we further restrict our sample to 5,900 births of children whose mother and biological father resided together at the nine-month interview (Wave 1). ${ }^{6}$ Resident fathers provided more information than non-resident fathers; therefore, this restricted sample enables us to include more father characteristics as predictors of relationship status at birth (cohabitation or marriage), including information on family background characteristics, as well as on fertility and relationship histories.

It is important to note, however, that the restricted sample is select in three important ways. First, it only includes those couples coresiding nine months after the birth of the child who were also coresiding at birth, and thus excludes those couples who transitioned to a coresidential union between the birth and nine months (see footnote \#6). Second, not all of the couples who were cohabiting or married at the birth of the focal child are included. Roughly $7 \%$ of all unions in which couples were either married or cohabiting at the birth had dissolved by the time of the nine-month survey, including $2 \%$ of marital unions and $29 \%$ of cohabiting unions. This means that our sample disproportionately represents relatively long-term, stable unions (in particular, cohabiting unions). Third, only $76 \%$ of fathers eligible to be in this restricted sample (i.e., living with the biological mother at birth and nine months after the birth of the focal child) filled out a resident father survey. To get a sense of how these selection criteria influence our sample, Appendix A compares our sample of resident fathers to 1) fathers who ended a coresidential union by Wave 1 (and filled out a non-resident survey), and 2) coresidential fathers who did not fill out a resident father survey. ${ }^{7}$ In general, our sample is selective of relatively more advantaged men, which is important to keep in mind when discussing the results of the analyses of the restricted sample.

\footnotetext{
${ }^{5}$ Unweighted sample sizes are rounded to the nearest 50 per requirements by NCES in the use of restricted data

${ }^{6} \mathrm{~A}$ total of 8,300 fathers were coresident at the time of the birth. From this sample, we removed 600 who ended their coresidential union by the nine-month survey. We also removed 1,800 who were coresident at birth and at the nine-month survey but who did not fill out a father survey, for a final sample of 5,900 fathers. Few couples coresiding at the 9-month survey were outside of a coresidential union at the time of the child's birth ( $1.5 \%$ of full sample $)$; therefore, this restricted sample only includes those coresiding nine months after the birth who were also coresiding at birth (i.e., married or cohabiting).

${ }^{7}$ Information on fathers who ended coresidential unions comes from the non-resident father survey. Although this survey is not as comprehensive as the resident father survey, it does include some basic demographic characteristics. Information on coresident fathers who did not fill out the resident father survey comes from mother reports.
} 
Compared to the fathers in our sample, those who were excluded because they ended coresidential union were more likely to be older, black, unemployed, have lower levels of education, and to identify the birth as unintended. In addition, those residential fathers who did not fill out a survey were more likely than our restricted sample to be Hispanic, and to have lower levels of education.

\subsection{Measures}

Dependent variable. Our dependent variable, the mother's relationship status at child's birth, has three categories: married to the biological father, cohabiting with the biological father, and outside a coresidential union (neither married to nor cohabiting) with the biological father at the child's birth. ${ }^{8}$ We determine whether the couple was married, cohabiting, or outside a union by comparing the child's birth date with the marriage and cohabitation start and end dates gathered in the marital history, and the partner relationship section of the parent questionnaire. Mothers who were separated from the biological father at the child's birth are classified as being outside a coresidential union.

Mother's individual characteristics. We include three measures of the mother's individual characteristics: age at birth, race/ethnicity, and education. For the mother's race/ethnicity, we distinguish between white, black, U.S.-born Hispanic, and foreignborn Hispanic women. These distinctions were made because an increasing body of research suggests that family formation patterns of Hispanics, and the meaning surrounding those forms, differs by nativity (Landale and Oropesa 2007). ${ }^{9}$ In the race/ethnicity specific models, we include a nativity variable for Hispanics. For maternal education, we use a variable which categorizes women as having 1) less than high school degree/certificate, 2) high school completion, 3) some college, and 4) college degree completion.

Mother's family background characteristics. We capture the mother's family background characteristics with three measures: family structure (whether the mother lived with both biological parents until age 16), parent education (1) less than high school, 2) high school completion, and 3) at least some college), and childhood economic status (whether the mother's family ever received Aid to Families of Dependent Children (AFDC) or welfare during her school-age years ${ }^{10}$ ).

\footnotetext{
${ }^{8}$ Too few women in the "outside a union" group were in a cohabiting relationship with someone other than the focal child's biological father to allow us to analyze these as a separate subgroup.

${ }^{9}$ Sample sizes did not allow us to disaggregate the Hispanic group into specific ethnic groups.

${ }^{10}$ AFDC and welfare are U.S. federal programs which we use as indicators of economic insecurity. Eligibility for these programs is based on specific family structure and income requirements that vary by state. http://aspe.hhs.gov/HSP/abbrev/afdc-tanf.htm.
} 
Manlove et al:: The relationship context of nonmarital childbearing in the U.S.

Mother's fertility and marriage history. We assess the mother's fertility and marriage history using two measures. First, we create a dichotomous measure of parity, comparing women with and without other births prior to the focal child. ${ }^{11}$ Second, we capture whether or not the mother had ever been married to someone other than the biological father prior to the birth of the focal child.

Father's individual characteristics. We include three measures of the father's individual characteristics: his age at the birth of the focal child, his education, and whether the father is the same race/ethnicity as the biological mother. We derive the father's age at the birth from the birth certificate; or, if it is missing on the birth certificate, from either the mother's report of the father's date of birth, or the father's self-report of his date of birth. Meanwhile, we derive the father's education from either the mother's or the father's report of his highest grade completed (and categorize this as we do for mother's). In analyses that include only variables reported by the mother, we use the mother's report of the father's date of birth and education. In analyses that include variables reported by the father, we start with the father's report, and then use the mother's report if the father's report is not available. The biological father was not asked to report directly on his race/ethnicity in the father questionnaire. Therefore, whenever possible, we use the mother's report of the household father's race/ethnicity, or we obtain the race of the biological father from the birth certificate. For the roughly 1,000 cases in which no biological father race/ethnicity was reported by the mother or on the birth certificate, we use the child's race/ethnicity as a proxy for father's. We recognize that using child's race/ethnicity is not a perfect proxy for father's race; however, we feel comfortable with this method, because in $89 \%$ of the cases in which race/ethnicity is available for both the father and the child, their races match. ${ }^{12}$

Father's family background characteristics. In models restricted to children living with resident fathers nine months after the birth, we include three measures of the father's family background characteristics (as reported by the fathers themselves): family structure (whether the father lived with both biological parents until age 16), parent education (the educational attainment of the father's more highly educated parent, measured as a three-category variable), and childhood economic status (whether the father's family ever received Aid to Families of Dependent Children (AFDC) or welfare during his school-age years).

Father's marriage history. We include one dummy measure of the father's marriage history that captures whether the father had ever been married to someone other than the biological mother prior to the birth of the focal child.

\footnotetext{
${ }^{11}$ The survey does not provide information about women's marital status at the time of prior births, so we are unable to determine if the prior births occurred inside or outside of marriage.

${ }^{12}$ In multivariate analyses, we include a flag variable for cases in which we use a child's race/ethnicity as a proxy for the father's race/ethnicity; this flag is associated with greater odds of cohabitation (versus marriage) and greater odds of being outside a union (versus marriage and cohabitation) at the focal child's birth.
} 
Parental fertility history. For the sample of children living with resident fathers nine months after the birth, we include one joint measure of prior fertility based on both the mother's and the father's reports. This measure has four categories: 1) neither the mother nor the father has any prior birth; 2) the mother has a prior birth and the father has a prior birth and all of the father's children live in the household; 3 ) the father has a prior birth and at least one of the father's prior children lives outside of the household; and 4) the mother has a prior birth, but the father does not. It should be noted that these categories are based on two measures of the father's prior fertility; specifically, his selfreport of any previous births and the number of children born outside the household. Mothers reported only whether or not they had a previous birth, and not whether the child resided inside or outside the household (in part because the vast majority of mothers live with their biological children (Kreider 2008)). Since the survey does not identify the biological parent of previous children, we cannot determine whether all children in Category 2 are the joint children of the mother and father. Some unknown proportion of these children, particularly of the mothers, will be with another partner. Additionally, some of the mothers in Category 3 will have previous children, including joint children with the father. Although the categorization of prior fertility is limited by the survey design, Category 2 identifies households in which all children (including stepchildren) reside together in one household, while Category 3 captures families who have children in multiple households.

Appendix B provides descriptive characteristics of the full sample and by race/ethnicity across all dependent and independent variables.

\subsection{Methods}

In the first set of analyses, we run multinomial logistic regression models on the full sample to examine how women's individual and family background characteristics, their fertility and marriage histories, and the characteristics of the biological fathers (as reported by the mothers) are associated with the women's relationship context at the time of a focal child's birth. This allows us to compare mothers who are cohabiting at the birth and mothers who are outside of a coresidential union to those who are married at the birth. To further explore the influence of father characteristics, our second set of analyses is limited to those mothers living with the focal child's biological father at the nine-month survey. This allows us to use an expanded set of father characteristics, as reported by the father. We run logistic regression models to assess how mothers' reports of mother characteristics and fathers' reports of father characteristics are associated with whether the couple was married versus cohabiting at the time of the focal child's birth. Both sets of analyses are run by race/ethnicity subgroups (comparing the relationship context of births to white, black, and Hispanic women), and z-tests were 
Manlove et al:: The relationship context of nonmarital childbearing in the U.S.

performed to assess significant differences in coefficients across race/ethnic-specific models. All analyses are weighted and adjusted for the data's clustered sampling design by using survey estimation procedures in Stata.

\section{Results}

\subsection{Relationship context at birth, by race/ethnicity}

One contribution of this study is to verify recent estimates of relationship status at birth. Figure 1 presents the distribution of the dependent variable in 2001 for the full sample, by race/ethnicity. Roughly $37 \%$ of all births occur to unmarried mothers $19 \%$ to cohabiting mothers, and $17 \%$ to mothers outside of a union. However, the distribution of relationship context at birth vary substantially across racial/ethnic subgroups. Threequarters $(76 \%)$ of births to white mothers occur within marriage, compared with over half (57\%) of births to foreign-born Hispanic mothers, $51 \%$ of births to native-born Hispanic mothers, and only $29 \%$ of births to black mothers. Thirty-one percent of births to foreign-born Hispanic mothers take place within cohabiting unions, compared to $26 \%$ of births to native-born Hispanics, $21 \%$ of births to blacks, and $14 \%$ of births to whites. Births to black women are much more likely than those to white or Hispanic women to occur outside a union. One-half of births to black women take place outside of a marital or cohabiting union, compared with $23 \%$ of births to native-born Hispanic women, and only $13 \%$ of births to foreign-born Hispanic women, and $9 \%$ of births to white women. 
Figure 1: Marital/cohabitation status of mothers at the time of birth, by race/ethnicity

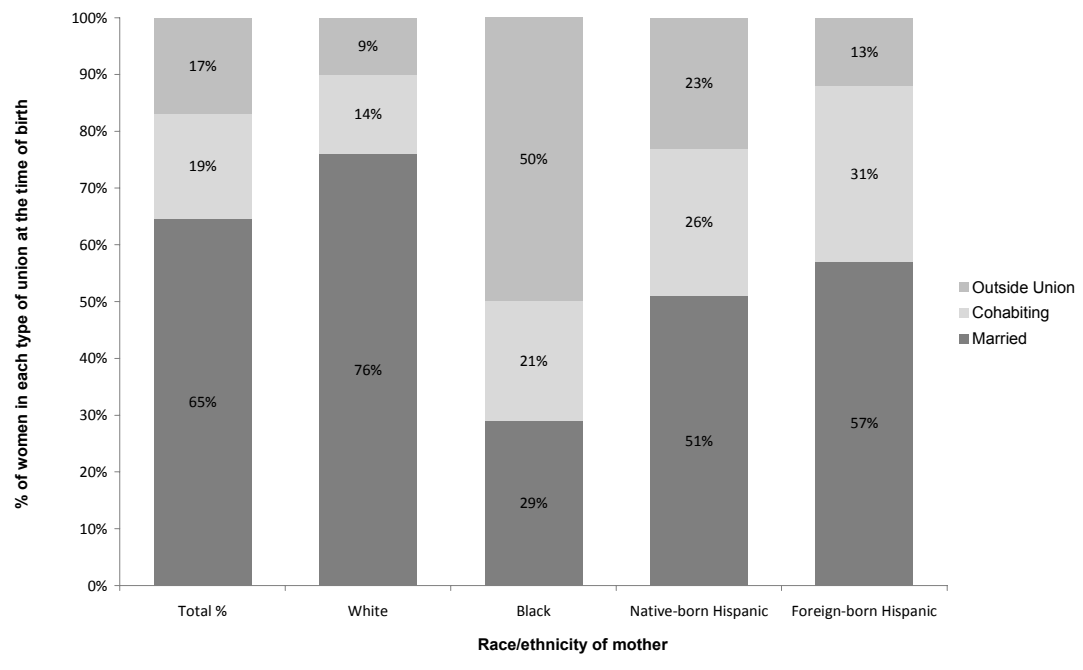

Focusing only on nonmarital births (Figure 2), we find that more than half (52\%) of nonmarital births occur to women who are cohabiting with the child's biological father. Again, however, we note large racial/ethnic differences. The majority of nonmarital births to Hispanic and white women take place within cohabiting unions ( $61 \%$ for white women, $53 \%$ for native-born Hispanic women, and $71 \%$ for foreignborn Hispanics), but only $29 \%$ of nonmarital births to black women occur within a cohabiting union. 
Manlove et al:: The relationship context of nonmarital childbearing in the U.S.

Figure 2: Percentage of nonmarital births occurring in cohabiting unions, by mother's race/ethnicity

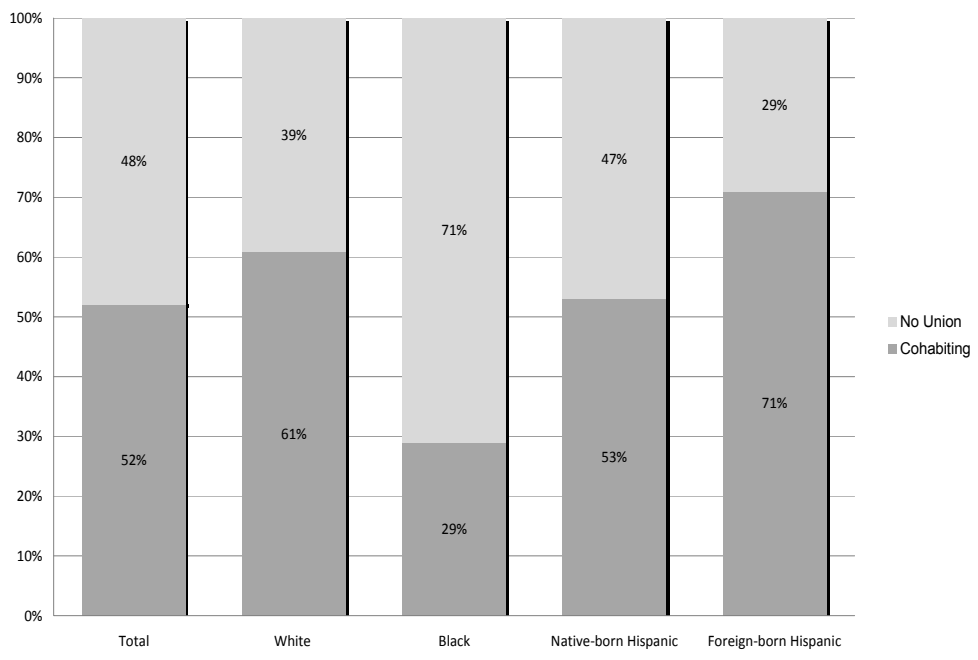

\subsection{Factors associated with relationship status at birth, full sample}

Table 1 displays findings from the multinomial logistic regression analyses, for the full sample and the racial/ethnic subsamples. Mother characteristics associated with a greater risk of cohabiting or being outside a union (vs. being married) at the time of the focal child's birth include being black or native-born Hispanic, and having been previously married to a man who is not the father of the focal child. Additionally, foreign-born Hispanic women have a greater risk of being in a cohabiting union at the birth, though not outside of a union (vs. being married). In contrast, the mother characteristics associated with a lower risk of being unmarried (and, therefore, a greater relative risk of being married) include being older at the child's birth, having at least a college degree, growing up in an intact family, and having previous children. 
Table 1: Relative risk ratios from multinomial logistic regression analyses of parents' relationship status at the child's birth, by race/ethnicity

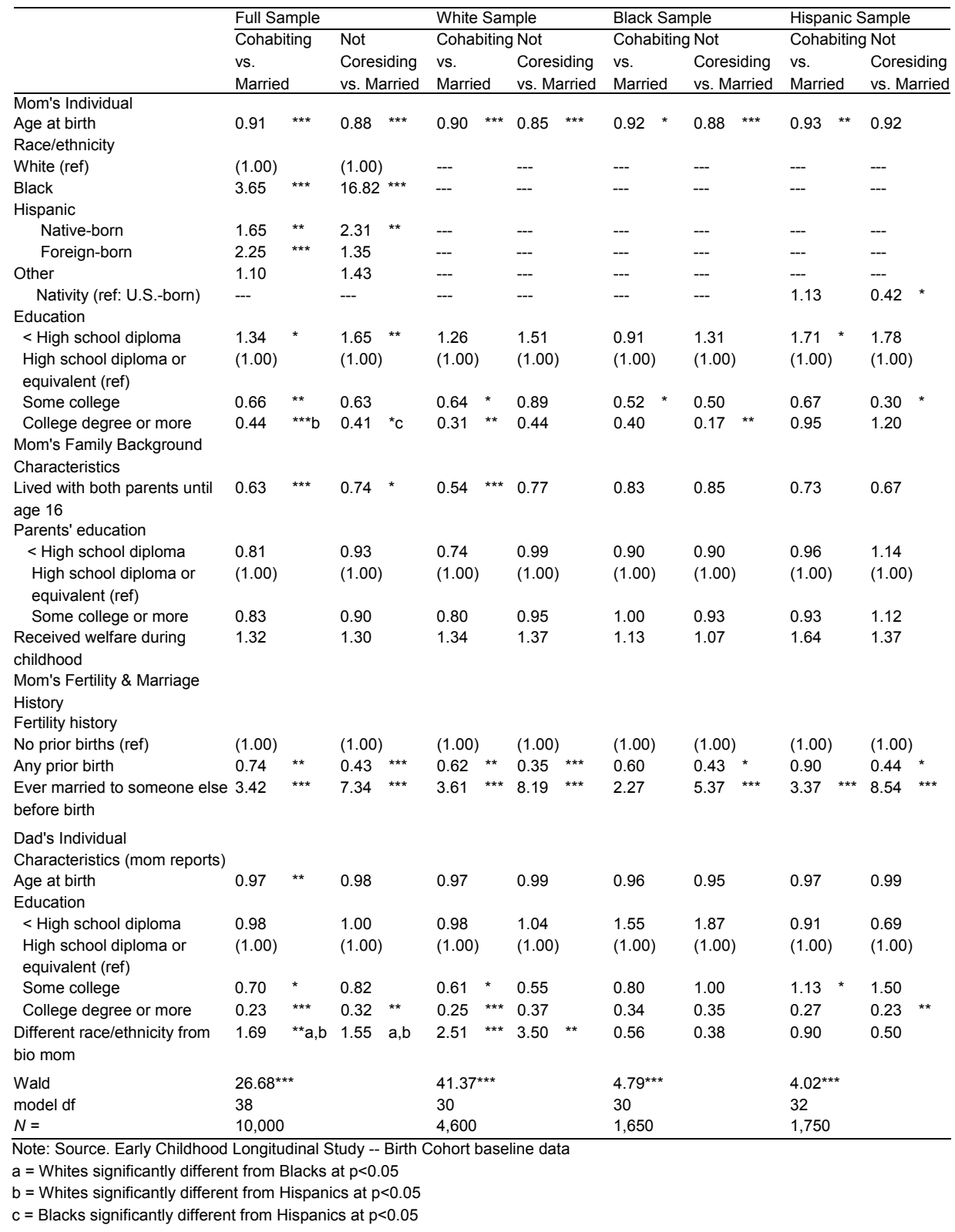

http://www.demographic-research.org 
Manlove et al:: The relationship context of nonmarital childbearing in the U.S.

Fathers' characteristics (as reported by mothers) have independent effects on the mothers' relationship context at birth, even after controlling for the mothers' own characteristics. Partnering with an older father or a father with at least some college is associated with a lower risk that the mother will be cohabiting (vs. married) at the birth of the focal child. Partnering with a father who has a college degree is also associated with a lower relative risk that a birth will take place outside of a union (vs. within marriage). In contrast, mothers have a higher risk of cohabiting (vs. being married) if their male partners are of a different race/ethnicity than themselves.

Subgroup analyses examine differences in the predictors of the relationship context at birth for whites, blacks, and Hispanics. First, however, it is worth noting that there are significant nativity differences in the risk of being outside of any coresidential union versus being married among Hispanics, with foreign-born Hispanics being more likely to be married than native-born Hispanics. However, there are no nativity differences in the likelihood of being in a cohabiting or marital union among those in a coresidential union. That said, of the maternal characteristics measured, we find that only having a college degree varies in its association with relationship status at birth across race/ethnic groups. Having a college degree reduces the likelihood of cohabitation (vs. marriage) for white mothers, but not for Hispanic mothers. Additionally, having a college degree increases the risk of marriage (vs. non-coresidential birth) for black mothers, but not for Hispanic mothers. Father characteristics also vary in their association with relationship status at birth. For white mothers, partnering with a father of a different race/ethnicity is associated with a greater risk of having a child in a nonmarital union; for black and Hispanic mothers, being of a race/ethnicity that is different from the race/ethnicity of the father is not associated with the risk of having a child outside a union, versus being married.

\subsection{Factors associated with relationship status at birth, restricted sample}

Table 2 displays findings from logistic regression analyses, comparing the odds of being in a cohabiting union relative to being married at the birth of the child, for the sample restricted to mothers who were still living with the focal child's biological father at the nine-month survey. Of the mothers' individual and family background characteristics, being black or foreign-born Hispanic and welfare recipient during childhood are found to be associated with increased odds of being in cohabiting union; whereas being older at the child's birth, having at least some college (or having a parent with some college), and living with both parents until age 16 are associated with reduced odds of cohabitation. When we look at the fathers' individual and family background characteristics, we find that mothers in relationships with fathers who were older and had a college degree at the birth of the focal child had reduced odds of being 
in a cohabiting versus marital union, whereas mothers who were partnered with fathers of a different race/ethnicity had increased odds of being in a cohabiting union.

Both the mothers' and the fathers' fertility and marriage histories are associated with the relationship status at the child's birth. Mothers who were divorced before the birth of the focal child, as well as those who are partnered with a father who was previously married, have much higher odds of being in a cohabiting union (compared with being married) at the time of the birth. Relative to couples with no prior children, couples with prior children - specifically, households in which all of the children are in one household - have greater odds of being married versus cohabiting at the birth of the focal child, while families in which only the woman had prior children with another partner have lower odds of being married. Couples in which at least one of the father's prior children lived in another household were no different from the reference group.

Subgroup analyses reveal relatively few racial/ethnic differences in the predictors of relationship context at birth among the sample of women living in coresidential unions nine months after the birth of the focal child. Notably, being a different race/ethnicity from the father is associated with increased odds of cohabitation for whites only (compared with blacks), whereas the father having been a welfare recipient in childhood is predictive of greater odds of cohabitation for black mothers only (compared with whites). The father's previous marital history is associated with greater odds of cohabitation for white, black, and Hispanic mothers, although the association is significantly greater for Hispanics than for black or white mothers. 
Manlove et al:: The relationship context of nonmarital childbearing in the U.S.

Table 2: Odds of cohabiting vs. marriage at birth among biological parents still coresiding nine months after the child's birth, by race/ethnicity

\begin{tabular}{|c|c|c|c|c|c|c|c|c|}
\hline & \multicolumn{2}{|c|}{$\begin{array}{l}\text { Restricted } \\
\text { Sample }\end{array}$} & \multicolumn{2}{|c|}{$\begin{array}{l}\text { Restricted } \\
\text { Sample, Whites }\end{array}$} & \multicolumn{2}{|c|}{$\begin{array}{l}\text { Restricted } \\
\text { Sample, Blacks }\end{array}$} & \multicolumn{2}{|c|}{$\begin{array}{l}\text { Restricted } \\
\text { Sample, Hispanics }\end{array}$} \\
\hline & OR & $p$ & OR & $\mathrm{P}$ & OR & $p$ & OR & $p$ \\
\hline \multicolumn{9}{|l|}{ Mom's Individual Characteristics } \\
\hline Age at birth & 0.91 & $* \star \star$ & 0.90 & ** & 0.86 & * & 0.93 & * \\
\hline \multicolumn{9}{|l|}{ Race/ethnicity } \\
\hline White (ref) & $(1.00)$ & & --- & & --- & & --- & \\
\hline Black & 3.43 & $* * *$ & -- & & --- & & --- & \\
\hline \multicolumn{9}{|l|}{ Hispanic } \\
\hline Native-born & 1.61 & & -- & & --- & & -- & \\
\hline Foreign-born & 2.51 & 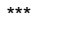 & --- & & --- & & -- & \\
\hline Other & 0.83 & & -- & & --- & & --- & \\
\hline Nativity (ref: U.S.-born) & --- & & --- & & --- & & 1.26 & \\
\hline \multicolumn{9}{|l|}{ Education } \\
\hline$<$ High school diploma & 1.32 & & 1.30 & & 0.73 & & 1.66 & \\
\hline High school diploma or equivalent (ref) & $(1.00)$ & & $(1.00)$ & & $(1.00)$ & & $(1.00)$ & \\
\hline Some college & 0.62 & ${ }^{* *} \mathrm{C}$ & 0.56 & * & 0.34 & & 1.18 & \\
\hline College degree or more & 0.45 & $* * *$ & 0.38 & ** & 0.31 & & 0.52 & \\
\hline \multicolumn{9}{|l|}{ Mom's Family Background Characteristics } \\
\hline Lived with both parents until age 16 & 0.66 & ** & 0.60 & ** & 1.32 & & 0.66 & \\
\hline \multicolumn{9}{|l|}{ Parents' education } \\
\hline$<$ High school diploma & 0.89 & & 0.88 & & 0.93 & & 0.71 & \\
\hline High school diploma or equivalent (ref) & $(1.00)$ & & $(1.00)$ & & $(1.00)$ & & $(1.00)$ & \\
\hline Some college or more & 0.71 & * & 0.79 & & 1.10 & & 0.42 & \\
\hline Received welfare during childhood & 1.76 & ** & 1.73 & * & 1.45 & & 2.33 & * \\
\hline \multicolumn{9}{|l|}{ Mom's Marriage History } \\
\hline Ever married to someone else before birth & 1.67 & ** & 2.03 & * & 1.74 & & 1.12 & \\
\hline \multicolumn{9}{|l|}{ Dad's Individual Characteristics (dad reports) } \\
\hline Age at birth & 0.93 & $* * *$ & 0.91 & *** & 0.97 & & 0.94 & * \\
\hline \multicolumn{9}{|l|}{ Education } \\
\hline$<$ High school diploma & 1.08 & & 0.98 & & 1.19 & & 0.86 & \\
\hline High school diploma or equivalent (ref) & $(1.00)$ & & $(1.00)$ & & $(1.00)$ & & $(1.00)$ & \\
\hline Some college & 0.85 & $a, c$ & 0.75 & & 1.59 & & 0.81 & \\
\hline College degree or more & 0.43 & ** & 0.40 & ** & 1.39 & & 0.48 & \\
\hline Different race/ethnicity from bio mom & 1.59 & *a & 2.35 & ** & 0.42 & & 1.06 & \\
\hline \multicolumn{9}{|l|}{ Dad's Family Background Characteristics } \\
\hline Lived with both parents until age 16 & 0.87 & & 0.79 & & 0.61 & & 1.08 & \\
\hline \multicolumn{9}{|l|}{ Parents' education } \\
\hline$<$ High school diploma & 0.82 & & 0.89 & & 0.37 & & 1.23 & \\
\hline High school diploma or equivalent (ref) & $(1.00)$ & & $(1.00)$ & & $(1.00)$ & & $(1.00)$ & \\
\hline Some college or more & 1.08 & & 1.10 & & 0.35 & & 1.68 & \\
\hline Received welfare during childhood & 1.32 & a & 0.95 & & 3.34 & * & 1.67 & \\
\hline \multicolumn{9}{|l|}{ Dad's Marriage History } \\
\hline Ever married to someone else before birth & 7.47 & ${ }^{* * *} \mathrm{~b}, \mathrm{c}$ & 6.19 & *** & 3.17 & * & 17.28 & *** \\
\hline \multicolumn{9}{|l|}{ Parent Fertility } \\
\hline No prior births (ref) & $(1.00)$ & & $(1.00)$ & & $(1.00)$ & & $(1.00)$ & \\
\hline Couple has prior birth, no child outside of household & 0.58 & $* * *$ & 0.43 & *** & 0.60 & & 0.78 & \\
\hline Father has prior birth, child outside of household & 0.99 & & 0.80 & & 0.95 & & 0.83 & \\
\hline Mother-only prior birth & 2.61 & $* * *$ & 1.88 & & 3.08 & & 3.53 & * \\
\hline Wald & 28.34 & 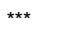 & 20.65 & *** & 2.33 & ** & 8.69 & $\star \star \star *$ \\
\hline model df & 27 & & 23 & & 23 & & 24 & \\
\hline$N=$ & 5,900 & & 3,250 & & 400 & & 900 & \\
\hline
\end{tabular}

Source: Early Childhood Longitudinal Study -- Birth Cohort baseline data

${ }^{*} \mathrm{p}<.05 .{ }^{* *} \mathrm{p}<.01 .{ }^{* * *} \mathrm{p}<.001 . \quad a=$ Whites significantly different from Blacks at $p<0.05$

$b=$ Whites significantly different from Hispanics at $p<0.05 \quad c=$ Blacks significantly different from Hispanics at $p<0.05$ 


\section{Summary and discussion}

\subsection{Levels and trends in nonmarital and cohabiting births in the U.S.}

Data from the early 1990 s indicated that $28 \%$ of all births in the U.S. were to unmarried women, and that $39 \%$ of nonmarital births (and $11 \%$ of all births) were to women in cohabiting relationships (Bumpass and Lu 2000). Using data from the Early Childhood Longitudinal Study-Birth Cohort, we find that, in 2001, 35\% of births were to unmarried mothers. In addition, our study indicates that $52 \%$ of nonmarital births (and $19 \%$ of all births) occurred within cohabiting unions. These figures are striking because they represent substantial growth in nonmarital and cohabiting births, with increases of $32 \%$ in nonmarital births and $71 \%$ in cohabiting births since the early 1990 s, including a $33 \%$ increase in the percentage of nonmarital births that occur within cohabiting unions (Bumpass and $\mathrm{Lu} 2000$ ).

Our findings are comparable to estimates from the 2001 vital statistics in the U.S. (34\% of births were nonmarital) (Martin et al. 2002), and to findings from the National Survey of Family Growth (NSFG), which show that $34 \%$ of children were born to unmarried parents during 1997-2001 (Kennedy and Bumpass 2008). Additionally, our findings are comparable to published Fragile Families data, which indicates that approximately one-half of all nonmarital births between 1998 and 2000 in the U.S. were to cohabiting women (Sigle-Rushton and McLanahan 2002); and to NSFG data, which show that 53\% of nonmarital births between 1997 and 2001 occurred to cohabiting parents (Kennedy and Bumpass 2008). The advantages of our study are that the ECLSB data offer a much larger sample of children than the NSFG data (approximately 10,000 versus 2,300 children, respectively), and that the ECLS-B is a nationally representative sample of births while the NSFG is a sample of individuals. Early estimates from the Fragile Families data were questioned because the sample is disproportionately urban and low-income (McLanahan et al. 2001). Our estimates, in conjunction with findings from the $2002 \mathrm{NSFG}$, suggest that the increase in the proportion of nonmarital births to cohabiting women in the U.S. is, in fact, a real increase.

The increase in nonmarital births in the U.S., and particularly in cohabiting births, is one of the central changes in family structure that characterize the Second Demographic Transition (SDT), and it is consistent with increases seen in many western industrialized countries. It is worth noting that the SDT has come under criticism as an explanation of changing family structure across countries, with researchers instead emphasizing the interrelatedness of structural and value-change explanations for the change. However, it is clear that SDT is useful as a general term describing the multiple facets of change in family structure many countries have witnessed over the past several decades (Perelli-Harris et al. 2010; Sobotka 2008). Of 
Manlove et al:: The relationship context of nonmarital childbearing in the U.S.

these changes, cohabitation, along with childbearing within cohabiting unions, have been subjected to extensive scrutiny in Europe and in the United States, with increasing evidence suggesting that the role cohabitation plays in family life is context dependent, and varies dramatically between individuals, between (and within) countries, and over time (Fussell, Gauthier, and Evans 2007; Heuveline and Timberlake 2004; Liefbroer and Dourleijn 2006; Perelli-Harris et al. 2010; Smock 2000; Sobotka and Toulemon 2008). Additionally, it appears that countries move towards increased cohabitation in different ways, with structural factors being more important in some countries in some historical time periods (i.e., cohabitation is more common among those with fewer resources), and ideational change being more important in other countries and time periods (Perelli-Harris et al. 2010; Sobotka 2008).

Within the U.S., there is continued debate over the role that cohabitation plays in the family system, with evidence suggesting it works as either an alternative to marriage, or a precursor to marriage, depending on the historical time period and the socioeconomic status and the race/ethnicity of the partners (Raley 2001; Seltzer 2004; Smock 2000). Overall, however, the evidence indicates that children born to cohabiting couples in the U.S. may be at greater risk for adverse outcomes than those born to married parents (Nelson, Clark, and Acs 2001). Some of this may be due to the fact that cohabitation in the U.S., along with childbearing within cohabitation, have been and continue to be closely tied to socioeconomic disadvantages (Kiernan 2004b; Lesthaeghe and Neidert 2006; Seltzer 2004; Sobotka 2008). However, some of these outcomes may also be due to the lack of formal and informal supports that are generally associated with marriage in the U.S. (Kiernan 2004a, Seltzer 2004). Additionally, although children born to married couples contribute to the stability of their parents' marriage, children born into cohabiting unions appear to have no stabilizing effect on their parents' unions in the U.S., as they do in some other European countries, where cohabitation is more institutionalized (Manning 2004; Sobotka and Toulemon 2008). Children of cohabiting parents may, however, have advantages over children born to single, non-cohabiting mothers, in that they have access to the presence of two adults, and, potentially, to two incomes (Acs and Nelson 2002). Cohabiting parents are also more likely to marry than are parents who have children outside of a cohabiting union (Manning 1993).

Despite the baseline racial/ethnic variation in cohabiting births, our study also finds that births within cohabiting unions in the U.S. have increased since the early 1990s for all racial/ethnic groups. Bumpass' and Lu's earlier work (2000) found that half of the births to unmarried white women, $53 \%$ of births to unmarried Hispanic women, and $22 \%$ of births to unmarried black women occurred within the context of cohabiting unions. Our updated estimates show that, in 2001, $61 \%$ of unmarried white mothers, $64 \%$ of unmarried Hispanic mothers (53\% native born, $71 \%$ foreign born), and $29 \%$ of unmarried black mothers gave birth while in cohabiting unions. These results are similar to those found by Kennedy and Bumpass (2008), with one exception. Using 
the 2002 NSFG, they estimated that $40 \%$ of births to unmarried black women occurred within cohabiting unions, compared to our finding of $29 \%$. These differences may be due to different sampling strategies across surveys.

Overall, comparisons of our findings with those of Bumpass and Lu suggest a shift from marital to cohabiting births among whites and Hispanics, as the percentage of births outside of marriage and to cohabiting couples increased between the 1990s and 2001, while the percentage of births to single women remained relatively unchanged. Among Hispanics, some of this shift may be due to due to increased immigration between 1990 and 2000. Although foreign-born Hispanics are similar to whites in the likelihood of having a coresidential birth, those coresidential births are much more likely to be to cohabiting than to married couples. Among blacks, however, there has been an increase in births to cohabiting couples, accompanied by a stabilization in the percentage of births that occur outside of marriage ( $72 \%$ in the early 1990 s, and $72 \%$ in our estimates), indicating that the increase in cohabiting births among black women largely reflects a shift from single to cohabiting births. As Kennedy and Bumpass (2008) noted, this means that an increasing proportion of black children are being born into two-parent households.

\subsection{Mother and father correlates of relationship status at birth}

Consistent with prior literature in the U.S. (Carlson, McLanahan, and England 2004; Landale and Forste 1991; South 2001; Upchurch, Lillard, and Panis 2002), we find that, among women, being younger, being a racial/ethnic minority, having less education, and growing up without both biological parents in the household are all associated with a greater risk of having a nonmarital birth (either within or outside of cohabitation), compared with a marital birth, in both of our samples. Our study shows that fathers' characteristics have additional, independent effects on the relationship status at birth, even after controlling for mothers' characteristics, in both samples. Women who partner with men who are older and have higher levels of education are less likely to have a nonmarital birth (vs. marital) than those who partner with younger, less educated fathers. Additionally, these same factors increase the odds of a having been married, rather than cohabiting, at the time of birth among our more select sample of women who are still in a coresidential union nine months after the birth. This is consistent with research in the U.S. showing that younger men have lower odds of becoming a father while married than while cohabiting (Joyner, Yang, and Peters 2005).

Consistent with the life course perspective (Elder 1998), our findings illustrate the important role of both mothers' and fathers' marriage and fertility histories, net of individual and family characteristics, and suggest that marriage and fertility histories are inextricably linked to later family transitions (Fomby and Cherlin 2007: 
Manlove et al:: The relationship context of nonmarital childbearing in the U.S.

Goldscheider and Sassler 2006). When we examine only the mother's past history (among the full sample; shown in Table 1), we find that the presence of other children, many of whom are likely shared with the current partner, seems to encourage women to have subsequent children within coresidential unions.

We get a more complete picture, however, when we incorporate men's marriage and fertility histories into the analyses (among the restricted sample; see Table 2). Among couples still coresiding nine months after the birth, we find that, if a woman has previous children (but the father does not), she faces increased odds of being unmarried (cohabiting vs. married) at the birth of a subsequent child. To illustrate the size of this effect, we note that a woman who has a previous child at the time of birth, while the father of the child does not, has a $12 \%$ probability of being in a cohabiting union, compared to a $7 \%$ probability for a woman giving birth in a relationship in which neither partner had a previous child. ${ }^{13}$ Prior research has also linked nonmarital childbearing to reduced odds of later marriage (Bennett, Bloom, and Miller 1995; Clarkberg, Stolzenberg, and Waite 1995; Lichter and Graefe 2001), and increased odds of cohabitation relative to marriage (Bennett, Bloom, and Miller 1995; Qian, Lichter, and Mellott 2005). The negative effect of previous children on the chances of remarriage may be due, in part, to the fact that children may be viewed by women's potential partners as a resource drain (Lampard and Peggs 1999).

An advantage of our data is, however, the ability to include a more complex fertility measure, at least in the more restricted sample. Using this measure, we find that, as hypothesized, couples among whom all the father's children live in one household (likely reflecting joint children of the mother and father) are more likely to be married (a predicted probability of $96 \%$ ) versus cohabiting (a predicted probability of $4 \%$ ) at the time of the focal birth than are couples with no prior children (a 93\% predicted probability of marriage and a $7 \%$ probability of cohabitation). The small positive effect of this measure on marriage may reflect a higher level of commitment in the relationship, or the fact that women see prior shared children (or men's prior children who live in the household) as indicative a man's strong family orientation (Stewart, Manning, and Smock 2003). In contrast, couples still coresiding nine months after the birth among whom only the father has previous children with another partner (living outside the household), regardless of the woman's prior fertility, are no different from childless couples in their odds of being in a cohabiting versus a marital union, perhaps precisely because the child is non-residential and consequently creates less strain in the relationship. Interestingly, prior research has found that the level of involvement of men with their non-residential children matters to subsequent union formation, such that more father involvement with non-resident children increases the odds of union formation (particularly cohabitation) among men (Stewart, Manning, and Smock 2003). We cannot measure the validity of this finding here, although it is clearly

\footnotetext{
${ }^{13}$ Predicted probabilities estimated with all other variables held at their mean. Analyses not shown.
} 
an important dimension of prior fertility. Nonetheless, consistent with our hypotheses, we find that women's and men's fertility histories are both important, and influence family formation in distinct ways.

With respect to marital histories, we find that a history of marriage to another man is associated with a greater risk of nonmarital childbearing in both samples. Additionally, among those still in a coresidential union nine months after the birth, we find that being partnered with a previously married man is associated with increased odds of being in a cohabiting versus a married union. A more complex family history, as indicated by previous marital relationships, may be reflective of characteristics (such as depression or stress due to increased family tensions) that make stable unions harder to create or maintain (Cherlin 2008). These findings are, however, inconsistent with one study that found a negative association between prior marriage and nonmarital childbearing, but only for black women (Upchurch, Lillard, and Panis 2002). The differences may be due in part to the fact that researchers examined births from an earlier time period (1979 to 1991) and the transition to a nonmarital birth among women, instead of looking at the relationship context of mothers at the births of their children.

\subsection{Racial/ethnic variation in correlates of relationship status at birth}

Despite observing large racial and ethnic differences in relationship statuses at birth, our results show that relatively few characteristics varied across racial/ethnic groups in their association with the relationship status at birth, in either the full sample or in the more restricted sample. First, white mothers whose male partners are of a different race/ethnicity are found to have an increased risk of having nonmarital (vs. marital) and cohabiting (vs. married) births than white women with a same-race/ethnicity partner. This finding is consistent with prior research that finds cohabiting couples are more likely to be interracial than married couples (Blackwell and Lichter 2004), and that interracial couples are less likely to marry than same-race couples, perhaps reflecting the greater social barriers to interracial marriage (Joyner and Kao 2005). Second, among couples still coresiding nine months after the birth of the focal child, we see a stronger association between the father's marital history and greater odds of a cohabiting birth (vs. marital) for Hispanic women than for white or black women. This may in part reflect a greater attitudinal support of cohabitation (if the arrangement is expected to be followed by marriage) as a context in which to have children among certain Hispanic groups (Oropesa 1996). Finally, among couples coresiding nine months after the birth, black women whose partners received welfare while growing up were significantly more likely to be in a cohabiting relationship (vs. marriage), while this association was not significant for white women. Given that this restricted sample 
Manlove et al:: The relationship context of nonmarital childbearing in the U.S.

is of above-average socioeconomic status, this finding may partly reflect the greater uncertainty surrounding romantic unions, and marriage in particular, among black women in the face of socioeconomic disadvantages (Burton and Tucker 2009). Historically, father and couple characteristics have been understudied in research examining family formation among women in the U.S.; our findings suggest that father characteristics are an important component of the social context within which fertility decisions are made.

\subsection{Limitations}

Our analyses have some limitations, primarily stemming from data restrictions. Many of our measures are restricted to sociodemographic characteristics, which are nonetheless valuable given the limited number of existing studies on predicting relationship context at birth. Ideally, however, we would have liked to have had information on other relevant factors, such as the length of the current relationship prior to the woman becoming pregnant with the focal child, relationship quality data, and more detailed marriage and fertility histories. For example, we know that women with nonmarital first births are more likely to have subsequent births outside of marriage (Driscoll et al. 1999), but the data do not allow us to determine if these previous births occurred within or outside of marriage. In addition, our measure of couple-level fertility histories cannot identify whether prior births occurred with the same partner or with a different partner. We would also have liked to have included the family backgrounds and marriage and fertility histories for all fathers, but this information was only available for resident fathers nine months after the birth of the child. Thus, in the analyses presented in Table 2, we compare children born within marriage to those born within longer term cohabiting unions who also responded to the survey; a group who are somewhat more advantaged. This means that some of our findings in the restricted sample may be due to selection, and may not be applicable to all couples who have children together.

Despite these limitations, our paper has several strengths. Our research uses relatively recent, nationally representative data that enable us to assess cohabiting births separately from births outside of a union. We also incorporate measures of mothers' and fathers' family background characteristics and their fertility and marriage histories. This represents an important contribution, because, although retrospective, the measures allow us to capture information about the parents' lives prior to the birth of the focal child; such measures are often unavailable in other datasets. Finally, our sample sizes

are large enough to allow us to examine critical racial/ethnic subpopulations in separate analyses. 


\section{Conclusion}

The increase in nonmarital fertility has been examined extensively in Europe and the United States. In the U.S., the federal government has made reducing nonmarital childbearing an explicit goal of welfare reform legislation. The Temporary Assistance for Needy Families (TANF) legislation specifies two objectives of relevance: (a) prevent and reduce the incidence of out-of-wedlock pregnancies, and (b) encourage the formation and maintenance of two-parent families (Administration for Children and Families 2010). This focus on the reduction of nonmarital childbearing and the formation of two-parent families stems from concerns about the negative consequences of nonmarital childbearing for both women and children. It is important to recognize, however, that more than half of nonmarital births occur within cohabiting unions, and that, regardless of the explicit role that cohabitation plays in the family system (Raley 2001; Seltzer 2004; Smock 2000), this percentage is increasing across all racial/ethnic groups. For whites and Hispanics, this reflects a decrease in the percentage of children being born to married parents, while for blacks it represents a decline in the percentage of children born to non-coresidential parents. Thus, with the exception of black children, most children born to unmarried mothers are starting off life with two biological parents in the household; and, in fact, the percentage of black children in two-parent households at birth is actually increasing.

The increase in childbearing within cohabiting unions reflects changes seen in many western industrialized countries (Kiernan 2004b; Sobotka and Toulemon 2008). However, for most groups in the U.S., cohabitation is not yet equivalent to marriage in terms of the benefits for child well-being (Acs and Nelson 2002; Manning and Brown 2006; Manning, Smock, and Majudmar 2004). Furthermore, 70\% of pregnancies that occur within unmarried cohabiting relationships in the U.S. are unintended (Finer and Henshaw 2006). By contrast, the majority of nonmarital births in many western and northern European countries are planned (Sobotka and Toulemon 2008). Nonetheless, these cohabiting couples with children have high expectations of marriage (Waller and McLanahan 2005), and are more likely than non-coresidential couples to have planned the birth (Finer and Henshaw 2006; Musick 2002). Thus, cohabiting parents appear to be an ideal group to target when the goal is to strengthen families. It is by no means clear, however, that marriage promotion policies will, by themselves, actually work as intended. This is because, despite the overwhelming dominance of marriage at a symbolic level in the U.S., substantial economic and social barriers to marriage remain among many unmarried parents, particularly among racial/ethnic minorities and those with fewer socioeconomic resources (Burton and Tucker 2009; Cherlin 2004; GibsonDavis, Edin, and McLanahan 2005). Policymakers may therefore wish to consider emphasizing programs that promote stability among unmarried parents, even if they continue to cohabit, and to focus more of their efforts on helping couples avoid unintended pregnancies. 
Manlove et al:: The relationship context of nonmarital childbearing in the U.S.

\section{Acknowledgements}

We gratefully acknowledge research support from the National Institute of Child Health and Human Development through grant R01 HD044761-04. We also thank Emily Holcombe, Erin Schelar, Sarah Cottingham, and Nicole Steward-Streng for their valuable research assistance. 


\section{References}

Acs, G. and Nelson, S. (2001). "Honey I'm home": Changes in living arrangements in the late 1990s (Assessing the New Federalism policy brief B-38). Washington, DC: The Urban Institute.

Acs, G. and Nelson, S. (2002). The kids are alright? Children's well-being and the rise in cohabitation (Series B No. B-48). Washington, DC: The Urban Institute.

Administration for Children and Families (2010). Office of family assistance: Fact sheets. [Electronic resource]. http://www.acf.hhs.gov/opa/fact_sheets/ tanf_factsheet.html.

Amato, P.R. (2000). The consequences of divorce for adults and children. Journal of Marriage and the Family 62(4): 1269-1287. doi:10.1111/j.17413737.2000.01269.x.

Andersson, G. (2002). Children's experience of family disruption and family formation: Evidence from 16 FFS countries. Demographic Research 7(7): 343-364. doi:10.4054/DemRes.2002.7.7.

Bachrach, C., Hindin, M.J., and Thomson, E. (2000). The changing shape of ties that bind: An overview and synthesis. In: Waite, L.J., Bachrach, C., Hindin, M. et al. (eds.). The Ties that Bind (pp. 3-16). New York: Aldine de Gruyter.

Bengston, V.L. and Allen, K.R. (1993). The life course perspective applied to families over time. In: Boss, P.G., Doherty, W.J., LaRossa, R., Schumm, W.R., Steinmetz, S.D. (Ed.). Sourcebook of family theories and methods: A contextual approach. New York: Plenum Press: 469-504.

Bennett, N.G., Bloom, D.E., and Miller, C.K. (1995). The influence of nonmarital childbearing on the formation of first marriages. Demography 32(1): 47-62. doi:10.2307/2061896.

Bernhardt, E.M. and Goldscheider, F.K. (2002). Children and union formation in Sweden. European Sociological Review 18: 289-299. doi:10.1093/esr/18.3.289.

Blackwell, D. and Lichter, D.T. (2004). Homogamy among dating, cohabiting, and married couples. The Sociological Quarterly 45(4): 719-737. doi:10.1111/j.1533-8525.2004.tb02311.x.

Bronfenbrenner, U. (1979). The ecology of human development. Cambridge: Harvard University Press. 
Manlove et al:: The relationship context of nonmarital childbearing in the U.S.

Bumpass, L. and Lu, H. (2000). Trends in cohabitation and implications for children's family contexts in the United States. Population Studies 54(1): 29-41. doi:10.1080/713779060.

Burton, L.M. and Tucker, M.B. (2009). Romantic unions in an era of uncertainty: A post-Moynihan perspective on African American women and marriage. Annals of the American Academy of Political and Social Science 621: 132-148. doi:10.1177/0002716208324852.

Carlson, M., McLanahan, S., and England, P. (2004). Union formation in fragile families. Demography 41(2): 237-261. doi:10.1353/dem.2004.0012.

Castro Martin, T. (2002). Consensual unions in Latin America: Persistence of a dual nuptiality system. Journal of Comparative Family Studies 33(1): 35-55.

Chandra, A., Martinez, G., Mosher, W.D., Abma, J., and Jones, J. (2005). Fertility, family planning, and reproductive health of U.S. women: Data from the 2002 National Survey of Family Growth. Vital Health Statistics 23(25).

Cherlin, A. (2008). Multiple partnerships and children's wellbeing. Family Matters (80): 33-36.

Cherlin, A.J. (2004). The deinstitutionalization of American marriage. Journal of Marriage and Family 66: 848-861. doi:10.1111/j.0022-2445.2004.00058.x.

Clarkberg, M., Stolzenberg, R., and Waite, L.J. (1995). Attitudes, values, and entrance into cohabitational versus marital unions. Social Forces 74(2): 609-634. doi: $10.2307 / 2580494$.

Driscoll, A.K., Hearn, G.K., Evans, V.J., Moore, K.A., Sugland, B.W., and Call, V. (1999). Nonmarital childbearing among adult women. Journal of Marriage and the Family 61(1): 178-187. doi:10.2307/353892.

East, P.L. (1998). Racial and ethnic differences in girls' sexual, marital, and birth expectations. Journal of Marriage and the Family 60(1): 150-162. doi: $10.2307 / 353448$.

Edin, K. and Kefalas, M. (2005). Promises I can keep: Why poor women put motherhood before marriage. Berkeley, CA: University of California Press.

Elder, G.H., Jr. (1998). The life course as developmental theory. Child Development 69(1): 1-12.

Ermisch, J. (2001). Cohabitation and childbearing outside marriage in Britain. In $\mathrm{Wu}$, L.L. and Wolfe, B. (eds.). Out of wedlock: Causes and consequences of nonmarital fertility. New York: Russell Sage Foundation. 
Finer, L.B. and Henshaw, S.K. (2006). Disparities in rates of unintended pregnancy in the United States, 1994 and 2001. Perspectives on Sexual and Reproductive Health 38(2): 90-96. doi:10.1363/3809006.

Flanagan, K.D. and West, J. (2004). Children born in 2001: First results from the base year of the Early Childhood Longitudinal Study, Birth Cohort (ECLS-B). (NCES 2005-036). U.S. Department of Education, Washington, DC: National Center for Education Statistics.

Fomby, P. and Cherlin, A. (2007). Family instability and child well-being. American Sociology Review 71(2): 181-204. doi:10.1177/000312240707200203.

Forste, R. and Tienda, M. (1996). What's behind racial and ethnic fertility differentials? Population and Development Review 22: 109-133. doi:10.2307/2808008.

Fussell, E., Gauthier, A.H., and Evans, A. (2007). Heterogeneity in the transition to adulthood: The cases of Australia, Canada, and the United States. European Journal of Population 23(3-4): 389-414. doi:10.1007/s10680-007-9136-4.

Gibson-Davis, C.M., Edin, K., and McLanahan, S. (2005). High hopes but even higher expectations: The retreat from marriage among low-income couples. Journal of Marriage and Family 67(5): 1301-1312. doi:10.1111/j.1741-3737.2005.00218.x.

Goldscheider, F.K. and Sassler, S. (2006). Creating stepfamilies: Integrating children into the study of union formation. Journal of Marriage and Family 68: 275-291. doi:10.1111/j.1741-3737.2006.00252.x.

Gryn, T. and Mott, F. (2002). Paternal relationship history and male fertility: Evidence from the NLSY. Paper presented at the Meetings of the Population Association of America, Atlanta, GA.

Guzman, L., Wildsmith, E., Manlove, J., and Franzetta, K. (2010). Unintended births: Patterns by race and ethnicity and relationship type. Perspectives on Sexual and Reproductive Health 42(3): 176-185.

Hamilton, B.E., Martin, J.A., and Ventura, S.J. (2009). Births: Preliminary data for 2007. National Vital Statistics Report 57(12). Hyattsville, MD: National Center for Health Statistics.

Hamplova, D. and Bourdais, C.L. (2009). One pot or two pot strategies? Income pooling in married and unmarried households in comparative perspective. Journal of Comparative Family Studies 40(3): 355-385.

Heard, H. (2007). Fathers, mothers and family structure: Family trajectories, parent gender, and adolescent schooling. Journal of Marriage and Family 69(2): 435450. doi:10.1111/j.1741-3737.2007.00375.x. 
Manlove et al:: The relationship context of nonmarital childbearing in the U.S.

Heuveline, P. and Timberlake, J.M. (2004). The role of cohabitation in family formation: The United States in comparative perspective. Journal of Marriage and Family 66(5): 1214-1230. doi:10.1111/j.0022-2445.2004.00088.x.

Huinink, J. and Feldhaus, M. (2009). Family research from the life course perspective. International Sociology 24: 299-324. doi:10.1177/0268580909102910.

Joyner, K. and Kao, G. (2005). Interracial relationships and the transition to adulthood. American Sociological Review 70(4): 563-582. doi:10.1177/000312240507 000402 .

Joyner, K., Yang, F., and Peters, H.E. (2005). Changes in early biological fatherhood and its relationship context. Paper presented at the Association for Public Policy Analysis and Management, Washington, D.C.

Kalmijn, M. (2007). Explaining cross-national differences in marriage, cohabitation, and divorce in Europe, 1990-2000. Population Studies 61(3): 243-263. doi:10.1080/00324720701571806.

Kennedy, S. and Bumpass, L. (2008). Cohabitation and children's living arrangements: New estimates from the United States. Demographic Research 19(47): 16631692. doi:10.4054/DemRes.2008.19.47.

Kiernan, K. (2001). European perspectives on nonmarital childbearing. In Wu, L.L. and Wolfe, B. (eds.). Out of wedlock: Causes and consequences of nonmarital fertility. New York: Russell Sage Foundation.

Kiernan, K. (2004a). Redrawing the boundaries of marriage. Journal of Marriage and Family 66: 980-987. doi:10.1111/j.0022-2445.2004.00068.x.

Kiernan, K. (2004b). Unmarried cohabitation and parenthood in Britain and Europe. Law and Policy 26(1): 33-55. doi:10.1111/j.0265-8240.2004.00162.x.

Kreider, R.M. (2008). Living arrangements of children: 2004. U.S. Census Bureau.

Lampard, R. and Peggs, K. (1999). Repartnering: The relevance of parenthood and gender to cohabitation and remarriage among the formerly married. British Journal of Sociology 50: 443-465. doi:10.1111/j.1468-4446.1999.00443.x.

Landale, N.S. and Forste, R. (1991). Patterns of entry into cohabitation and marriage among mainland Puerto Rican women. Demography 28: 587-607. doi:10.2307/2061424.

Landale, N.S. and Oropesa, R.S. (2007). Hispanic families: Stability and change. Annual Review of Sociology 33: 381-405. doi:10.1146/annurev.soc.33.0404 06.131655 . 
Lesthaeghe, R.J. and Neidert, L. (2006). The second demographic transition in the United States: Exception or textbook example? Population and Development Review 32(4): 669-698. doi:10.1111/j.1728-4457.2006.00146.x.

Lichter, D.T. and Graefe, D.R. (2001). Finding a mate? The marital and cohabitation histories of unwed mothers. In: Wu, L.L. and Wolfe, B. (eds.). Out of wedlock: Causes and consequences of nonmarital fertility. New York: Russell Sage Foundation: 317-343.

Liefbroer, A.C. and Dourleijn, E. (2006). Unmarried cohabitation and union stability: Testing the role of diffusion using data from 16 European countries. Demography 43(2): 203-221. doi:10.1353/dem.2006.0018.

Manning, W. (1993). Marriage and cohabitation following premarital conception. Journal of Marriage and the Family 55(4): 839-850. doi:10.2307/352766.

Manning, W. (2001). Childbearing in cohabiting unions: Racial and ethnic differences. Family Planning Perspectives 33(5): 217-224. doi:10.2307/2673785.

Manning, W. (2004). Children and the stability of cohabiting couples. Journal of Marriage and the Family 66(3): 674-689. doi:10.1111/j.0022-2445.2004. 00046.x.

Manning, W.D. and Brown, S. (2006). Children's economic well-being in married and cohabiting parent families. Journal of Marriage and Family 68(2): 345-362. doi:10.1111/j.1741-3737.2006.00257.x.

Manning, W.D., Smock, P.J., and Majudmar, D. (2004). The relative stability of cohabiting and marital unions for children. Population Research and Policy Review 23(2): 135-159. doi:10.1023/B:POPU.0000019916.29156.a7.

Martin, J.A., Hamilton, B.E., Sutton, P.D., Ventura, S.J., Menacker, F., Kirmeyer, S., and Matthews, T.J. (2009). Births: Final data for 2006. National Vital Statistics Reports 57(7). Hyattsville, MD: National Center for Health Statistics.

Martin, J.A., Hamilton, B.E., Ventura, S.J., Menacker, F., and Park, M.M. (2002). Births: Final data for 2001. National Vital Statistics Reports 51(5). Hyattsville, MD: National Center for Health Statistics.

McLanahan, S., Garfinkel, I., Reichman, N., Teitler, J., Carlson, M., and Audigier, C. (2001). The fragile families and child wellbeing study baseline report. Princeton, N.J.: CRCW.

McLanahan, S. and Sandefur, G.D. (1994). Growing up with a single parent: What hurts, what helps. Cambridge, MA: Harvard University Press. 
Manlove et al:: The relationship context of nonmarital childbearing in the U.S.

Mincieli, L., Manlove, J., McGarrett, M., Moore, K.A., and Ryan, S. (2007). The relationship context of births outside of marriage: The rise of cohabitation. Washington, DC: Child Trends.

Moore, K.A. (1995). Executive summary: Report to Congress on out-of-wedlock childbearing. [Electronic resource]. Washington D.C.: Government Printing Office. http://www.cdc.gov/nchs/data/misc/wedlock.pdf

Musick, K. (2002). Planned and unplanned childbearing among unmarried women. Journal of Marriage and Family 64(4): 915-929. doi:10.1111/j.17413737.2002.00915.x.

Nelson, S., Clark, R.L., and Acs, G. (2001). Beyond the two-parent family: How teenagers fare in cohabiting couple and blended families (Series B No. No. B31). Washington, DC: The Urban Institute.

Neyer, G. and Andersson, G. (2004). Contemporary research on European fertility: Introduction. Demographic Research 3(1): 1-13. doi:10.4054/DemRes.2004. S3.1.

Nock, S.L. (1998). The consequences of premarital fatherhood. American Sociological Review 63: 250-263. doi:10.2307/2657326.

Oropesa, R.S. (1996). Normative beliefs about marriage and cohabitation: A comparison of non-Latino whites, Mexican Americans, and Puerto Ricans. Journal of Marriage and the Family 58(1): 49-62. doi:10.2307/353376.

Osborne, C., Manning, W.D., and Smock, P.J. (2004). Instability in Fragile Families: The role of race-ethnicity, economics, and relationship quality. Paper presented at the American Sociological Association, San Francisco, CA.

Perelli-Harris, B., Sigle-Rushton, W., Kreyenfeld, M., Lappegard, T., Berghammer, C., and Keizer, R. (2010). The educational gradient of nonmarital childbearing in Europe: Emergence of a pattern of disadvantage? [Unpublished manuscript], WP 2010-004, Germany: Max Planck Institute for Demographic Research.

Qian, Z., Lichter, D.T., and Mellott, L.M. (2005). Out-of-wedlock childbearing, marital prospects and mate selection. Social Forces 84(1): 473-491. doi:10.1353/ sof.2005.0117.

Raley, R.K. (2001). Increasing fertility in cohabiting unions: Evidence for the second demographic transition in the United States. Demography 38(1): 59-66. doi:10.1353/dem.2001.0008. 
Sassler, S. and McNally, J. (2003). Cohabiting couples' economic circumstances and union transitions: A re-examination using multiple imputation techniques. Social Science Research 32: 553-578. doi:10.1016/S0049-089X(03)00016-4.

Seltzer, J. (2000). Men's contributions to children and social policy. In A. Booth and A. Crouter (Eds.), Men in families: When do they get involved? What difference does it make? Mahwah, NJ: Lawrence Erlbaum Associates.

Seltzer, J.A. (2004). Cohabitation in the United States and Britain: Demography, kinship, and the future. Journal of Marriage and Family 66(4): 921-928. doi:10.1111/j.0022-2445.2004.00062.x.

Seltzer, J.A., Bachrach, C.A., Bianchi, S.M., Bledsoe, C.H., Casper, L.M., ChaseLansdale, P.L., DiPrete, T.A., Hotz, V.J., Morgan, S.P., Sanders, S.G., and Thomas, D. (2005). Explaining family change and variation: Challenges for family demographers. Journal of Marriage and Family 67: 908-925. doi:10.1111/j.1741-3737.2005.00183.x.

Sigle-Rushton, W. and McLanahan, S. (2002). The living arrangements of new unmarried mothers. Demography 39(3): 415-433. doi:10.1353/dem.2002.0032.

Smock, P. (2000). Cohabitation in the United States: An appraisal of research themes, findings, and implications. Annual Review of Sociology 26(1): 1-20. doi:10.1146/annurev.soc.26.1.1.

Sobotka, T. (2008). Overview chapter 6: The diverse faces of the second demographic transition in Europe. Demographic Research 19(8): 171-224. doi:10.4054/Dem Res.2008.19.8.

Sobotka, T. and Toulemon, L. (2008). Overview chapter 4: Changing family and partnership behaviour: Common trends and persistent diversity across Europe. Demographic Research 19(6): 85-138. doi:10.4054/DemRes.2008.19.6.

Soons, J.P.M. and Kalmijn, M. (2009). Is marriage more than cohabitation? Well-being differences in 30 European countries. Journal of Marriage and Family 71: 11411157. doi:10.1111/j.1741-3737.2009.00660.x.

South, S.J. (2001). The variable effects of family background on the timing of first marriage: United States, 1969-1993. Social Science Research 30: 606-626. doi:10.1006/ssre.2001.0714.

Stewart, S.D., Manning, W.D., and Smock, P.J. (2003). Union formation among men in the U.S.: Does having prior children matter? Journal of Marriage and Family 65(1): 90-104. doi:10.1111/j.1741-3737.2003.00090.x. 
Manlove et al:: The relationship context of nonmarital childbearing in the U.S.

Upchurch, D.M., Lillard, L.A., and Panis, C.W.A. (2001). The impact of nonmarital childbearing on subsequent marital formation and dissolution. In: $\mathrm{Wu}, \mathrm{L} . \mathrm{L}$. and Wolfe, B. (eds.). Out of wedlock: Causes and consequences of nonmarital fertility. New York: Russell Sage Foundation: 344-380.

Upchurch, D.M., Lillard, L.A., and Panis, C.W.A. (2002). Nonmarital childbearing: Influences of education, marriage, and fertility. Demography 39(2): 311-329. doi:10.1353/dem.2002.0020.

Ventura, S.J. (2009). Changing patterns of nonmarital childbearing in the United States. Hyattsville, MD: National Center for Health Statistics.

Ventura, S.J., Bachrach, C.A., Hill, L., Kaye, K., Holcomb, P., and Kiff, E. (1995). The demography of out-of-wedlock childbearing. In: Report to Congress on Out-ofWedlock Childbearing. Washington, DC: U.S. Government Printing Office: 3133.

Vos, A.E. (2009). Falling fertility rates: New challenges to the European welfare state. Socio-Economic Review 7: 485-503. doi:10.1093/ser/mwp007.

Waller, M.R. and McLanahan, S. (2005). "His" and "her" marriage expectations: Determinants and consequences. Journal of Marriage and Family 67: 53-67. doi:10.1111/j.0022-2445.2005.00005.x.

Wildsmith, E. and Raley, R.K. (2006). Race-ethnic differences in nonmarital fertility: A focus on Mexican American women. Journal of Marriage and Family 68: 491508. doi:10.1111/j.1741-3737.2006.00267.x.

Wu, L.L. and Wolfe, B. (2001). Out of wedlock: Causes and consequences of nonmarital fertility. New York: Russell Sage Foundation. 
Demographic Research: Volume 23, Article 22

\section{Appendix A: Sample characteristics of resident fathers, nonresident fathers, and resident fathers with missing nine-month surveys}

\begin{tabular}{|c|c|c|c|c|c|c|}
\hline & \multicolumn{2}{|l|}{ Resident } & \multicolumn{2}{|c|}{ Nonresident } & \multicolumn{2}{|c|}{ Missing Father } \\
\hline & Fathers $^{a}$ & $\mathrm{M} / \%$ & Fathers $^{b}$ & $\mathrm{M} / \%$ & Data $^{c}$ & $\mathrm{M} / \%$ \\
\hline \multicolumn{7}{|l|}{ Father Characteristics } \\
\hline \multicolumn{7}{|l|}{ Pregnancy Characteristics } \\
\hline Intended & $59.2 \%$ & & $39.1 \%$ & & $\mathrm{n} / \mathrm{a}$ & \\
\hline Unintended & $40.8 \%$ & & $60.9 \%$ & & $\mathrm{n} / \mathrm{a}$ & \\
\hline Age in years (at birth of focal child) & 33.0 & & 40.7 & & 33.9 & \\
\hline Mental health (9 months) & 3.6 & & 7.5 & & $\mathrm{n} / \mathrm{a}$ & \\
\hline \multicolumn{7}{|l|}{ Race/ethnicity } \\
\hline White & $70.5 \%$ & & $49.0 \%$ & & $51.3 \%$ & \\
\hline Black & $7.0 \%$ & & $30.4 \%$ & & $12.2 \%$ & \\
\hline Hispanic & $18.5 \%$ & & $17.1 \%$ & & $30.5 \%$ & \\
\hline Other & $4.0 \%$ & & $3.5 \%$ & & $6.0 \%$ & \\
\hline \multicolumn{7}{|l|}{ Father's employment status (9 months) } \\
\hline Employed & $88.6 \%$ & & $66.5 \%$ & & $85.8 \%$ & \\
\hline Not employed & $11.4 \%$ & & $33.5 \%$ & & $14.2 \%$ & \\
\hline \multicolumn{7}{|l|}{ Father's education level (9 months) } \\
\hline Less than high school & $17.0 \%$ & & $24.1 \%$ & & $33.0 \%$ & \\
\hline High school & $21.5 \%$ & & $42.6 \%$ & & $26.9 \%$ & \\
\hline Some college & $28.0 \%$ & & $27.1 \%$ & & $20.7 \%$ & \\
\hline College degree or more & $33.5 \%$ & & $6.1 \%$ & & $19.5 \%$ & \\
\hline Number of children (9 months) & 2.0 & & 1.9 & & $\mathrm{n} / \mathrm{a}$ & \\
\hline \multicolumn{7}{|l|}{ Mother characteristics } \\
\hline \multicolumn{7}{|l|}{ Pregnancy characteristics } \\
\hline Intended & $74.4 \%$ & & $37.5 \%$ & & $63.1 \%$ & \\
\hline Unintended & $25.6 \%$ & & $62.6 \%$ & & $36.9 \%$ & \\
\hline Age in years (at birth of focal child) & 28.6 & & 23.8 & & 27.9 & \\
\hline \multicolumn{7}{|l|}{ Mother's employment status (9 months) } \\
\hline Employed & $95.1 \%$ & & $83.6 \%$ & & $93.6 \%$ & \\
\hline Not employed & $4.9 \%$ & & $16.4 \%$ & & $6.4 \%$ & \\
\hline$N=$ & 5,900 & & 200 & & 1,800 & \\
\hline
\end{tabular}

Source: Early Childhood Longitudinal Study -- Birth Cohort baseline data

a. Resident father characteristics taken from resident father survey

b. Non-resident father characteristics taken from non-resident father survey

c. Missing resident father characteristics taken from mother survey 
Manlove et al:: The relationship context of nonmarital childbearing in the U.S.

Appendix B: Characteristics of biological parents of children born in 2001, by race/ethnicity

\begin{tabular}{|c|c|c|c|c|}
\hline & $\begin{array}{l}\text { Full } \\
\text { Sample } \\
\text { Tot al }\end{array}$ & $\begin{array}{l}\text { White } \\
\text { Sample }\end{array}$ & $\begin{array}{l}\text { Black } \\
\text { Sample }\end{array}$ & $\begin{array}{l}\text { Hispanic } \\
\text { Sample }\end{array}$ \\
\hline Weighted $\mathrm{N}=$ & 10,000 & 4,600 & 1,650 & 1,750 \\
\hline \multicolumn{5}{|l|}{ Mom's Individual Characteristics } \\
\hline $\begin{array}{l}\text { Mean age at birth of focal child } \\
\text { Race/ethnicity }\end{array}$ & 27.3 & 28.1 & 25.2 & 26.2 \\
\hline White & $57.4 \%$ & - & - & - \\
\hline Black & $14.1 \%$ & - & - & - \\
\hline \multicolumn{5}{|l|}{ Hispanic } \\
\hline Native-born & $8.4 \%$ & - & - & 37.2 \\
\hline Foreign-born & $14.2 \%$ & - & - & 62.8 \\
\hline Other & $5.9 \%$ & - & - & - \\
\hline \multicolumn{5}{|l|}{ Education } \\
\hline$<$ High school diploma & $27.2 \%$ & $16.5 \%$ & $33.6 \%$ & $51.7 \%$ \\
\hline High school diploma or equivalent & $21.9 \%$ & $21.4 \%$ & $29.5 \%$ & $19.6 \%$ \\
\hline Some college & $26.5 \%$ & $29.4 \%$ & $26.7 \%$ & $18.9 \%$ \\
\hline College degree or more & $24.4 \%$ & $32.7 \%$ & $10.2 \%$ & $9.8 \%$ \\
\hline \multicolumn{5}{|l|}{ Mom's Family Background Characteristics } \\
\hline $\begin{array}{l}\text { Lived with both parents until age } 16 \\
\text { Parents' education }\end{array}$ & $58.2 \%$ & $62.2 \%$ & $35.5 \%$ & $61.1 \%$ \\
\hline$<$ High school diploma & $25.8 \%$ & $13.2 \%$ & $25.0 \%$ & $58.7 \%$ \\
\hline High school diploma or equivalent & $26.9 \%$ & $29.3 \%$ & $37.1 \%$ & $15.2 \%$ \\
\hline Some college or more & $47.3 \%$ & $57.5 \%$ & $37.9 \%$ & $26.2 \%$ \\
\hline $\begin{array}{l}\text { Received welfare during childhood } \\
\text { Mom's Fertility \& Marriage History } \\
\text { Parity }\end{array}$ & $10.8 \%$ & $8.0 \%$ & $23.4 \%$ & $9.9 \%$ \\
\hline No prior births & $40.1 \%$ & $40.0 \%$ & $37.6 \%$ & $40.9 \%$ \\
\hline Any prior births & $59.9 \%$ & $60.0 \%$ & $62.4 \%$ & $59.1 \%$ \\
\hline Ever married to someone else before birth & $14.8 \%$ & $17.4 \%$ & $9.5 \%$ & $12.2 \%$ \\
\hline
\end{tabular}




\section{Appendix B: (Continued)}

\begin{tabular}{|c|c|c|c|c|}
\hline \multirow{2}{*}{$\begin{array}{l}\text { Dad's Individual Characteristics (mom } \\
\text { reports) }\end{array}$} & $\begin{array}{l}\text { Full } \\
\text { Sample } \\
\text { Tot al }\end{array}$ & $\begin{array}{l}\text { White } \\
\text { Sample }\end{array}$ & $\begin{array}{l}\text { Black } \\
\text { Sample }\end{array}$ & $\begin{array}{l}\text { Hispanic } \\
\text { Sample }\end{array}$ \\
\hline & & & & \\
\hline Mean age at birth of focal child & 29.8 & 30.5 & 28.3 & 28.8 \\
\hline > High school diploma & $27.9 \%$ & $18.6 \%$ & $30.6 \%$ & $52.0 \%$ \\
\hline High school diploma or equivalent & $22.6 \%$ & $21.5 \%$ & $33.1 \%$ & $19.8 \%$ \\
\hline Some college & $25.4 \%$ & $27.4 \%$ & $26.4 \%$ & $19.9 \%$ \\
\hline College degree or more & $24.2 \%$ & $32.5 \%$ & $9.9 \%$ & $8.3 \%$ \\
\hline Education & 4.2 & 4.5 & 3.5 & 2.9 \\
\hline Different race/ethnicity from bio mom & $11.6 \%$ & $9.3 \%$ & $5.2 \%$ & $13.2 \%$ \\
\hline Weighted $\mathrm{N}=$ & 5,900 & 3,250 & 400 & 950 \\
\hline \multicolumn{5}{|l|}{$\begin{array}{l}\text { Dad's Individual Characteristics (dad } \\
\text { reports) }\end{array}$} \\
\hline Age at birth & 31.0 & 31.3 & 31.8 & 29.5 \\
\hline \multicolumn{5}{|l|}{ Education } \\
\hline$<$ High school diploma & $17.0 \%$ & $8.6 \%$ & $16.0 \%$ & $46.9 \%$ \\
\hline High school diploma or equivalent & $21.5 \%$ & $21.4 \%$ & $31.8 \%$ & $20.6 \%$ \\
\hline Some college & $28.0 \%$ & $30.7 \%$ & $29.5 \%$ & $19.9 \%$ \\
\hline College degree or more & $33.5 \%$ & $39.4 \%$ & $22.7 \%$ & $12.6 \%$ \\
\hline Different race/ethnicity from bio mom & $11.0 \%$ & $7.0 \%$ & $9.0 \%$ & $15.6 \%$ \\
\hline \multicolumn{5}{|l|}{ Dad's Family Background Characteristics } \\
\hline Lived with both parents until age 16 & $68.0 \%$ & $69.0 \%$ & $51.8 \%$ & $68.8 \%$ \\
\hline \multicolumn{5}{|l|}{ Parents' education (range: 1 to 9) } \\
\hline$<$ High school diploma & $17.9 \%$ & $7.8 \%$ & $19.5 \%$ & $51.7 \%$ \\
\hline High school diploma or equivalent & $25.2 \%$ & $29.5 \%$ & $28.7 \%$ & $11.7 \%$ \\
\hline Some college or more & $57.0 \%$ & $62.8 \%$ & $51.8 \%$ & $36.5 \%$ \\
\hline $\begin{array}{l}\text { Received welfare during childhood } \\
\text { Dad's Marriage History }\end{array}$ & $10.1 \%$ & $8.8 \%$ & $20.5 \%$ & $11.1 \%$ \\
\hline Ever married to someone else before birth & $20.3 \%$ & $18.1 \%$ & $22.0 \%$ & $28.8 \%$ \\
\hline \multicolumn{5}{|l|}{ Parent Fertility } \\
\hline No prior births & $33.3 \%$ & $34.6 \%$ & $18.4 \%$ & $31.5 \%$ \\
\hline Couple has prior birth, no child outside & & & & \\
\hline household & $48.2 \%$ & $49.3 \%$ & $41.9 \%$ & $46.6 \%$ \\
\hline $\begin{array}{l}\text { Father has prior birth, child outside of } \\
\text { household }\end{array}$ & $12.6 \%$ & $10.3 \%$ & $31.8 \%$ & $16.0 \%$ \\
\hline Mother-only prior birth & $5.9 \%$ & $5.8 \%$ & $7.9 \%$ & $5.8 \%$ \\
\hline
\end{tabular}

Note. Source: Early Childhood Longitudinal Study -- Birth Cohort baseline data 
Manlove et al:: The relationship context of nonmarital childbearing in the U.S. 